\title{
Destek Ürünler ve COVID-19
}

\section{Dietary Supplements and COVID-19}

\section{Serdar CEYLAN'(ID), Didem KARADUMAN'(iiD), Çag̃layan Merve AYAZ²(iD), Burcu Balam DOG̃U'(iiD), Meltem Gülhan HALIL'(IID), Mustafa CANKURTARAN'(IiD)}

\author{
${ }^{1}$ Hacettepe Üniversitesi Tıp Fakültesi, Geriatri Bilim Dalı, Ankara, Türkiye \\ 2 Ankara Șehir Hastanesi, İnfeksiyon Hastalıkları ve Klinik Mikrobiyoloji Klinig̃i, Ankara, Türkiye
}

Makale atıfi: Ceylan S, Karaduman D, Ayaz ÇM, Doğu BB, Halil MG, Cankurtaran M. Destek ürünler ve COVID-19. FLORA 2021;26(3):353-60.

\section{ÖZ}

Çin'de ortaya çıkıp dünyaya yayılan SARS-CoV-2 virüsü, COVID-19 adıyla anılan hastalığa neden olmuş; sonucunda Dünya Sağlık Örgütü tarafından 11 Mart 2020'de pandemi olarak ilan edilmiştir. Insanlar için yeni bir virüs olan SARS-CoV-2, morbidite ve ölüm sayısında artışa neden olmuştur. Aşı ve ilaç alanındaki gelişmelere rağmen COVID-19'un olumsuz etkileri devam etmektedir. Morbidite ve mortalite yükü büyük tehdit oluşturan bir hastalık olan COVID-19 ortaya çıktıktan sonra virüsten korunmak ve yakalandıktan sonra hastalığı hafif atlatmak için çözümler aranmaya başlanmıştır. Güçlü bir immün sistemin infeksiyonlara karşı savaşta önemi bilindiğinden maske, mesafe ve hijyen önlemlerine ek olarak immüniteyi güçlendirecek yollar aranmaya başlanmıştır. Bu nedenle immün sistem üzerinde etkili olduğu düşünülen destek ürünlerinin popülaritesi artmıştır. Literatürde immünite ve diğer viral infeksiyonlarla ilgili olumlu çalışmalardan yola çıkılarak destek ürünlerin COVID-19'a karşı yararlı olabilecekleri düşünülmüş̧ür. COVID-19 hakkındaki randomize kontrollü çalışmaları az olan destek ürünlerle ilgili çoğunlukla gözlemsel çalışmalar yayınlanmıştır. Derlememizde destek ürünlerin immünite, diğer viral infeksiyonlar ve COVID-19 üzerine etkileri incelenmiştir.

Anahtar Kelimeler: COVID-19; Immünite; Vitamin D; Çinko

\section{ABSTRACT \\ Dietary Supplements and COVID-19 \\ Serdar CEYLAN', Didem KARADUMAN', Cag̃layan Merve AYAZ², Burcu Balam DOG̃U', Meltem Gülhan HALiL', Mustafa CANKURTARAN'}

\footnotetext{
${ }^{1}$ Division of Geriatrics, Hacettepe University Faculty of Medicine, Ankara, Turkey

${ }^{2}$ Clinic of Infectious Diseases and Clinical Microbiology, Ankara City Hospital, Ankara, Turkey
}

SARS-CoV-2 virus, which emerged in China and spread worldwide, caused the disease called COVID-19, and as a result, it was declared as a pandemic by the World Health Organization on March 11, 2020. SARS-CoV-2, a new virus for humans, has caused an increase in morbidity and mortality rates. Despite developments in vaccines and drugs, unfavorable effects of COVID-19 keep going. After the emergence of COVID-19, a disease that poses a great threat of morbidity and mortality, solutions have been searched to avoid from the virus and to overcome the disease after getting sick. As the importance of a strong immune system in the fight against infections is known, ways to strengthen immunity have been sought in addition to masks, distance and hygiene measures. For this reason, popularity

Geliș Tarihi/Received: 16/04/2021 - Kabul Ediliș Tarihi/Accepted: 30/07/2021

${ }^{\bullet}$ Telif Hakkı 2021 Flora. Makale metnine www.floradergisi.org web adresinden ulașılabilir 
of dietary supplements, which are thought to be effective on the immune system, has increased. Based on the positive studies on immunity and other viral infections in the literature, it is thought that dietary supplements can be useful against COVID-19. About dietary supplements on COVID-19, there are only a few randomized controlled studies, observational studies have been published mostly. In this review, the effects of dietary supplements on immunity, other viral infections and COVID-19 were examined.

Key Words: COVID-19; Immunity; Vitamin D; Zinc

\section{GíRiș}

Ilk olarak Aralı 2019'da Cin'de tanımlanan SARS-CoV-2, COVID-19 pandemisine yol açarak, 12 Nisan 2021 tarihi itibarıla dünya genelinde 130.000.000'dan fazla vaka ve 3.000.000'a yakın ölümle sonuçlanmıștır ${ }^{[1]}$. COVID-19'un mutlak tedavisi henüz bulunamamıstır; mevcut antiviral tedavilerin mortalite, hastane yatıs süresi ve ventilatör ihtiyac1 üzerine çok az etkilerinin olduğu ya da etkilerinin olmadığı gösterilmiștir ${ }^{[2]}$. Mortalite üzerine sadece steroidin üstün etkisinden bahsedilmis, bir meta-analizde sistemik kortikosteroid tedavisinin kritik COVID-19 hastalarında mortaliteyi azalttığı ortaya konmustur ${ }^{[3]}$. Alternatif tedavi arayıșında pek cok denemeye ihtiyac duyulmuștur. İmmün sistemi güçlendiren vitamin $\mathrm{D}$, vitamin $\mathrm{C}$, cinko, magnezyum, omega- 3 , koenzim $\mathrm{Q}_{10}$ gibi destek ürünleriyle ilgili calısmalar ve yayınlar artış göstermiștir. Geniș caplı ekolojik calıșmanın sonucunda immün sistemi güclendirecek destek ürünlerin kullanımıyla COVID-19 insidans veya mortalitesinde azalma arasında ilișki olabileceği belirtilmiștir ${ }^{[4]}$. Bu destek ürünlerin reçetesiz, kolay ulașılabilir olması nedeniyle toplumca tüketimlerinde de artıs görülmüștür.

Burada COVID-19 önlenmesi ve tedavisinde alternatif aday olabilecek basslıca destek ürünler incelenmiștir. Özellikle yayınlarda bahsedilen D vitamini, C vitamini, çinko, magnezyum, selenyum, omega-3, koenzim $\mathrm{Q}_{10}$, glutatyon, beta-glukan, resveratrol, kurkumin ve probiyotikler olmak üzere 12 adet destek ürüne derlememizde yer verilmiștir.

1. D vitamini: İmmünomodülatör etkileri olan D vitamini makrofajlar, dendritik hücreler, $\mathrm{T}$ ve $\mathrm{B}$ lenfositler üzerinde etkide bulunarak CXCL8 ve CXCL10 gibi kemokinleri, tümör nekrozis faktör $\alpha \quad(T N F-\alpha)$ ve interlökün-6 (IL-6) gibi sitokinleri düzenleyerek immün yanitı düzenlemektedir. Virüslerin replikasyonunu ve infektivitelerini azaltabileceğine yönelik bilgiler bulunmakla birlikte bu etkiler hücre kültürlerinde kesin olarak gösterilememiștir $^{[5]}$. Klinik calıșmalarda solunum yolu viral infeksiyonlarında olumlu etkileri gösterilen D vitamini için COVID-19 infeksiyonunda da benzer etkileri gösterebileceği düșüncesi akla gelmiștir ${ }^{[6,7]}$. Gözlemsel calıșmalarda D vitamini eksikliği olan bireylerin COVID-19'a daha yüksek oranda yakalandığı görülmektedir ${ }^{[7]}$. Buna karșılık İngiltere Sağlık Bilgi Bankası'ndan edinilen verilerde ise vitamin D ile COVID-19 infeksiyonu riski arasında ilișki olmadığı görülmüștür ${ }^{[8]}$. On çalıșma, 361.934 hastayı kapsayacak sekilde yapılmıs olan bir meta-analizde vitamin D eksikliği/yetersizliğinin COVID-19'a yakalanma riskini 1.43 kat arttırdığı gösterilmiștir ${ }^{[9]}$. On dört calıșmayı içeren bașka bir meta-analizde ise $\mathrm{D}$ vitamini eksikliği olan bireylerin COVID-19 infeksiyonuna yakalanma oranlarının \%80 daha fazla olduğu ortaya konmustur ${ }^{[10]}$. Ayrıca D vitamini eksikliği olanlar hastalarda kritik hastalığa ilerleme/mortalite riskinde artıș olmaktadır ancak hastanede yatmakta olan COVID-19 hastalarına tek doz 200000 IU D3 vitamini desteğinin hastanede kalıs süresinde azalmaya yol açmadığı görülmüștür ${ }^{[11,12]}$. COVID-19 hastalarının ev içi temashlarına D vitamini desteğiyle ilgili calıșma planlanmıs olup sonuçları henüz açıklanmamıștır ${ }^{[13]}$. Bu bilgiler 1 șığında yüksek risk grubundaki hastalara D vitamini takviyesinin faydalı olacağını belirten ve takviye verilmesini öneren derleme calıșmalar bulunmaktadır ancak daha fazla randomize kontrollü çalıșmaya ihtiyac duyulmaktadır ${ }^{[14]}$.

2. C vitamini: Antioksidan özellikteki $\mathrm{C}$ vitamini; patojenlere karșı epitel bariyeri sağlamlastırmakta, derinin antioksidan fonksiyonlarını arttırmaktadır. Nötrofil ve makrofajların fagositik aktivitelerini desteklemekte, T/B lenfositlerin farklılașmasını ve sayısını arttırarak yeterli antikor düzeyini sağlamaktadır. Sitokin üretimini düzenleyerek inflamatuvar yanitın düzeyinin belirlenmesine yardımcı olmaktadır. Vitamin C eksikliğinde 
infeksiyonlara duyarllıkta artıs görülmektedir ${ }^{[15]}$. $\mathrm{Bu}$ nedenlerle üst solunum yolu infeksiyonları semptomlarının önlenmesinde $\mathrm{C}$ vitamini etkili olabilmektedir ${ }^{[16]}$. Ayrica semptom görüldükten sonra semptom süresi ve siddetini de kisaltmaktadır ${ }^{[17]}$. Viral infeksiyonlardaki potansiyel olumlu etkileri göz önüne alınarak COVID-19 hastalarında da $C$ vitamini kullanımının erken ve gec dönemde yararlı olabileceği düșünülmektedir ${ }^{[18]}$. Yapilan calıșmalarda orta ve siddetli COVID-19 hastalarında C vitamini düzeylerinin düșük olduğu gözlenmiștir. İntravenöz (IV) C vitamini desteği uygulandığında inflamatuvar değerler ve oksijen ihtiyacında azalma olduğu görüilmüștür ${ }^{[19]}$. Bașka bir calıșmada ayaktan izlenen COVID-19 hastalarına 10 gün $8000 \mathrm{mg}$ C vitamini replasmanı, standart tedaviye göre semptom süresinde anlaml 1 azalmaya neden olmamıstır $^{[20]}$. Küresel capta C vitamini monoterapisinin COVID-19 hastaları üzerindeki etkilerini inceleyen calısmalar devam etmektedir. Derleme calıșmalar, daha çok gözlemsel calıșmalar ve klinik denemeler göz önünde bulundurularak yapilmıștır. Bunların sonuçarı umut verici olsa da randomize kontrolliu calıșmalara ihtiyaç duyulmaktadır. Mevcut veriler ısı̆̆ında sağlıklı bireylere ve COVID-19 tanılı hastalara C vitamini desteği rutin olarak önerilmemektedir ${ }^{[21,22]}$. Yine de gelișmekte olan ve az gelișmis ülkelerde kronik vitamin $\mathrm{C}$ eksikliği olabileceği akılda tutularak replasmanı düșünülebilir [23]

3. Çinko: Hücre bölünmesi (büyüme, yara iyileșmesi), apoptoz ve antioksidan mekanizmalar üzerinde etkili bir mineraldir. IL-6, TNF- $\alpha$, C-reaktif protein (CRP) gibi sitokinlerin salınımın azaltarak antiinflamatuvar etki göstermektedir ${ }^{[24]}$. Cinkonun COVID-19 dahil pek cok ribonükleik asid (RNA) virüsünde viral giriș ve replikasyon inhibisyonunda, ayrıca antiinflamatuvar etkiyle sitokin fırtınasının önlenmesi, mukosilier aktivite düzenlenmesinde rolü bulunmaktadır ${ }^{[25]}$. Hafif cinko yetersizlikleri bile hematopoezde ve immün fonksiyonlarda değisiikliklere neden olarak proinflamatuvar yolaklarda ve redoks metabolizmasında olumsuzluklara neden olmaktadir. İmmün sistem üzerindeki negatif etkilerin yanı sıra cinko alım azlı̆̆1 devam ederse birçok hücre tipinin isslevlerinde aksamalar meydana gelmektedir. Adezyon molekülleri ve sıkı bağlantı proteinleri azalırken hücre ölümleri artmaktadır. İnsan vücudu infek- siyonlara daha duyarlı hale gelmekte ve infeksiyonlar daha ağır seyredebilmektedir ${ }^{[26]}$. Bakımevlerinde yașayan yașlı bireylerde yapilan randomize kontrollü bir çalıșmada, serum çinko düzeyi daha düsüuk $(<70 \mu \mathrm{g} / \mathrm{dl})$ olanlarda pnömoni insidans1 ve süresinde artış; bir diğer calıșmada ise cinko takviyesiyle $\mathrm{T}$ hücre fonksiyonunda artıs gözlenmistirir ${ }^{[27,28]}$. Özellikle daha ağır seyirli COVID-19 riski nedeniyle yașl1, malnutrisyonu olan, immünitesi zayif gruplarda cinko takviyesi COVID-19 profilaksisinde akılda tutulmalıdır ${ }^{[29]}$. COVID-19 nedeniyle yatan hastaların bazal çinko değerleri düșük olduğunda yatıs süresi ve komplikasyonların $\operatorname{arttığ1~görülmektedir~}^{[30]}$. Hastanede izlenen $\mathrm{CO}$ VID-19 hastalarına cinko replasmanı ile olumlu sonuçlar alınabileceği düsünülmektedir. Bu nedenle solunum sikintisı olan ve hastanede yatan veya kritik durumdaki hastalardaki etkisini gözlemlemek için randomize kontrollü çalıșma planlamıșlardır; sonuçları henüz yayınlanmamıștır ${ }^{[31]}$. Sonuçları yayınlanan randomize kontrollü calısmada ise ayaktan izlenen COVID-19 hastalarına 10 gün boyunca $50 \mathrm{mg}$ cinko glukonat verilmesiyle standart tedaviye göre semptom süresinde anlaml kısalma görülmemiștir ${ }^{[20]}$. Derleme calıșmalar daha cok çinkonun immünite ve diğer viral infeksiyonlar üzerindeki etkilerine, cinko eksikliği olan hastalardaki gözlemsel verilere dayanarak dizayn edilmektedir ${ }^{[32,33]}$. COVID-19'dan korunmak ve yakalandıktan sonra destek amaçı çinko kullanımıyla kesin bilgiler bulunmamaktadır. Potansiyel olumlu etkilerine rağmen cinkonun yüksek dozlarda ve uzun süreli kullanımı toksisite riski tașıdığı, ayrıca immüniteyi baskılayabileceği için kullanımında dikkatli olunmalıdır.

4. Magnezyum: Vücutta birçok görevi olan magnezyum; $\mathrm{T}$ ve $\mathrm{B}$ lenfositleri, makrofajları, nötrofilleri etkileyerek inflamatuvar cevap, apoptoz, doğal ve kazanılmıs immünite üzerinde etkilerde bulunmaktadır ${ }^{[34]}$. Eksikliğinde viral infeksiyonlara karș1 direnc azalmaktadır. COVID-19 infeksiyonu farklı derecelerde solunum yolu semptomlarina ve organ hasarına neden olmaktadır. Magnezyum takviyesinin de organları antiinflamasyon, antioksidasyon, immün regülasyon dahil olmak üzere birçok mekanizma yoluyla hasardan koruduğu bilinmektedir. Viral infeksiyonlar için optimal beslenme durumlarını inceleyen bir calısmada ise magnezyum da dahil olmak üzere eser element 
desteklerinin alınmasının immün sistemi güçlendirerek infeksiyonlara karș korunmada rol oynayabileceği belirtilmektedir ${ }^{[35]}$. COVID-19 hastalarının incelendiği gözlemsel bir calıșmada magnezyumu düșük hastaların prognozunun daha kötü olduğu görülmüștür ${ }^{[36]}$. Özellikle hamile kadınlarda, hipertansiyon ve diyabet tanisı olan hastalarda COVID-19 önlenmesinde ve tedavisinde magnezyum replasmanı akılda tutulmalıdır ${ }^{[37,38]}$.

5. Selenyum: Vücutta birçok enzimin yap1sinda yer alan selenyum, redoks homeostazında önemli bir role sahiptir ve antioksidan özellikleri nedeniyle antiviral etkili mekanizmalarda görev almaktadır (39). Selenyum eksikliğinin viral mutasyon ve virülans ile bağlantılı olduğu düșünülmektedir ${ }^{[40]}$. Eksikliği ayrıca influenza A, insan immün yetmezlik virüsü, hepatit $\mathrm{C}$, Ebola gibi pek cok RNA virüsü infeksiyonuyla ilișki göstermektedir (41). Kore'de yapılan bir çalıșmada COVID-19 hastalık siddetiyle selenyum eksikliği korele izlenmis olup hafif vakalarda \%44.4 oranında, yüksek akım oksijen ihtiyacı olanlarda \%66.7, ekstrakorporeal membran oksijenizasyonu/mekanik ventilatör ihtiyacı olanlarda \%100, ölenlerde \%100 oranında selenyum eksikliği saptanmıștır $^{[42]}$. Almanya'da yapılan kesitsel bir calıșmada ise selenyum transportunda görevli selenoprotein $\mathrm{P}$ (SELENOP) düzeyi ile cinko düzeyinin kombine parametre olarak değerlendirilmesi sonucu bu kombine parametrenin düzeyindeki düșüklük sağliklı bireylerde \%0.15, hayatta kalan COVID-19 hastalarında \%19.7, yașamını yitiren COVID-19 hastalarında \%50.0 oranında bulunmustur. Bu parametrenin COVID-19 prognozu ve hayatta kalma oranında yol gösterici olabileceği düșunülmektedir. Cinkoyla selenyumun birlikte kullanımı umut vadeden bir tedavi yaklașımı olabilir ${ }^{[43]}$.

6. Omega-3: Poliansature yağ asidi (PAYA) grubunda yer alan omega-3, özellikle zarflı virüslerin zarf yapılarının yağ içeriğini değiștirerek antiviral etkinlik göstermektedir. Yüksek PAYA alımının pnömoni riskinde de azalmaya neden olabileceği düșünülmektedir ${ }^{[44]}$. Koekkoek ve arkadaşlarının yapmıs olduğu meta-analizde yoğun bakım ünitesinde kritik hastalarda enteral balık yağı desteğinin hastane mortalitesini değiștirmediği; akut respiratuvar distres sendromu (ARDS) gelișenlerde ise yoğun bakım ünitesinde yatıș süresi, ventilas- yon süresi ve mortalitede önemli ölcuide azalma sağladığı rapor edilmiștir ${ }^{[45]}$. Omega-3'ün antiviral etkinliğinin yanı sıra antiinflamatuar, antitrombotik etkileri de olup COVID-19 ilișkili trombotik olayları önleyebileceği ancak yan etki olarak oksidatif stres artıșına yola açabileceği ve viral klirensi azaltabileceği akılda tutulmalıdır[46]. COVID-19 ilișkili depresyon için PAYA desteğinin faydalı olabileceği öne sürülmüștür ${ }^{[45]}$. COVID-19 ilișkili olfaktör sinir disfonksiyona bağlı anozmi tedavisinde randomize kontrollü çalıșma devam etmektedir (ClinicalTrials.gov, NCT04495816). Antiinflamatuvar etkileri COVID-19 hastalarında kullanımı için gerekçe olabilecek omega-3 için daha fazla klinik veriye ihtiyac duyulmaktadir.

7. Koenzim $\mathbf{Q}_{\mathbf{1 0}}$ : Ana olarak enerji metabolizmasında görevli olan koenzim $\mathrm{Q}_{10}$ 'un immün sistem ile ilișkisi net olarak bilinmemektedir. Insan immün yetmezlik virüui ile infekte hastalarda replasmanıyla birlikte CD4 T hücre sayısında artıs, insan papilloma virüs ve herpes infeksiyonlarına bağlı cilt infeksiyonlarının düzelmesinde olumlu etki görüldüğui bildirilmiștir ${ }^{[47]}$. Fan L. ve arkadașlarının yürüttüğü meta-analizde koenzim $\mathrm{Q}_{10}$ 'un inflamasyonu kontrol altına aldığı; IL-6, TNF- $\alpha$ ve CRP konsantrasyonunda anlamlı düșüs sağladığı rapor edilmiștir ${ }^{[48]}$. Yapılan gözlemsel calıșmalarda ise influenza infeksiyonu gecirenlerde, sepsis ve septik sok hastalarında koenzim $Q_{10}$ düzeyini düșuik olduğu görülmüștür ${ }^{[49,50]}$. COVID-19 hastalarında inflamasyon sonucu mitokondriyal disfonksiyon meydana gelmektedir ${ }^{[51]}$. Mitokondriyal hedefli bir antioksidan olan koenzim $\mathrm{Q}_{10}$ 'un mitokondriyal disfonksiyonu geriletebileceği, COVID-19 hastalarında sitokin fırtınasını hafifletip ve $\mathrm{T}$ hücrelerinin ișlevinde artıșa neden olabileceği öne sürülmektedir ${ }^{[52]}$. Koenzim $\mathrm{Q}_{10}$ 'un viral proteaz inhibisyonu ve antiinflamatuvar etkileri nedeniyle özelikle sitokin fırtınasında COVID-19 tedavisinde aday olabileceği belirtilmektedir ${ }^{[53]}$.

8. Glutatyon: Güçlü bir antioksidan olan glutatyon; redoks dengesinin korunması, oksidatif stresin azaltılması, metabolik detoksifikasyon ve immün sistem fonksiyonlarının düzenlenmesinde görev almaktadır ${ }^{[54]}$. Glutatyonun reaktif oksijen türlerini azaltma etkisinden dolayı COVID-19 hastalarında görülen ağır inflamatuvar cevabı azaltabileceği öne sürülmektedir. Ayrıca prostoglandin 
ve tromboksan sentezindeki kofaktör rolü, nitrik oksit sentezindeki fonksiyonu nedeniyle vasküler yapinın korunmasında ve solunum yollarındaki daralmanın önlenmesinde etkili olabilmektedir ${ }^{[55]}$. İnsan immün yetmezlik virüsü, tüberküloz ve diğer pulmoner veya immünosupresif hastalıklarda da elde edilen veriler, glutatyonun COVID-19 icin ek bir tedavi olabileceğini düșündürtmektedir ${ }^{[56]}$. Amerika'dan iki hastanın olduğu vaka bildiriminde glutatyon replasmanının solunumsal semptomları ve dispneyi azalttığı görülmüștür. Oral ve IV glutatyonun yanı sira glutatyon öncüllerinin ( $\mathrm{N}-\mathrm{a}-$ setil-sistein, alfa-lipoik asit), nükleer faktör kappa $B(\mathrm{NF}-\kappa \mathrm{B})$ 'yi bloke etmek ve COVID-19 pnömonisi olan hastalarda sitokin fırtınası ve solunum sıkıntısıyla mücadele etmek için yeni bir tedavi yaklașımı olușturabileceği ileri sürüilmektedir [57].

9. Beta-glukan: Polisakkarit yapida bir madde olan beta-glukan, lökositleri aktive ederek ve proinflamatuvar sitokinkeri azaltarak immünomoduilator etkilerde bulunmaktadır ${ }^{[58]}$. Beta-glukan desteğiyle üst solunum yolu infeksiyonu semptomlarında ve buna bağlı is günü kaybında belirgin azalma izlenmektedir ${ }^{[59]}$. COVID-19 ilișkili sitokin fırtınasına yönelik in vitro bir calıșmada beta-glukan ekstresinin NF-кB aktivasyonunu azalttığı, gec apoptozisi önlediği, makrofaj ve proinflamatuvar sitokinleri baskıladığı, pulmoner sitoprotektif etkiler gösterdiği, sitokin fırtınası tedavisinde olumlu etkilerinin olabileceği sonucuna varılmıștır ${ }^{[60]}$. COVID-19 tedavi ve önlenmesinde beta-glukanın kullanıldığı randomize kontrollü herhangi bir çalıșma verisi yoktur. Önceki çalıșmalara dayanarak oral beta-glukan kullanımının bağıșıklık yanıtını destekleyebileceği, intestinal inflamasyonu ve tromboz riskini azaltabileceği, COVID-19 profilaksi ve tedavisinde için etkili, düșük maliyetli ve güvenli bir yol olabileceği varsayılabilir ancak bu tedavinin güvenliğini ve etkinliğini doğrulamak için klinik araștırmalar gerekmektedir [61]

10. Resveratrol: Antiinflamatuvar, antimikrobiyal ve antioksidan etkili bir polifenolduir ${ }^{[62]}$. Bașlıca doğal öldürücü hücreler ve makrofajlarda aktivasyon, $\mathrm{T}$ helper ve $\mathrm{B}$ lenfositlerde regülasyon, proinflamatuvar sitokinlerde inhibisyon gibi pek cok etkisi olup otoimmün ve kronik inflamatuvar hastalıklarda baskılanma sağladığı, antitümöral etkinliklerinin de olduğu gösterilmiștir ${ }^{[63]}$.
Influenza, respiratuvar sinsityal virüs, dengue, zika virüs gibi çok sayıda virüsün replikasyonunu azaltmaktadır ${ }^{[64]}$. Resveratrolün COVID-19 replikasyonunu baskıladığı, viral spike proteininin anjiyotensin dönüștürücü enzim 2 (ACE2) reseptörüne bağlanmasını inhibe ettiği in vitro olarak gösterilmiștir ${ }^{[65]}$. Biyoyararlanımın geliștirileceği nanoteknoloji tabanlı uygulamaların güvenlik ve etkinlik açısından klinik calıșmalarının yapılması resveratrol için umut verici olabilir.

11. Kurkumin: Antiinflamatuvar, antimikrobiyal ve immünomodülatör etkili; virüsün hücre içine girișini ve viral proteazı inhibe eden, zerdeçalda bulunan bir polifenoldür ${ }^{[66]}$. Antiviral etkisinin yanı sira antiinflamatuvar, antioksidan, antiapoptotik, antifibrotik etkileri bulunmaktadır. Bu etkilerin yanı sıra proinflamatuvar sitokinler, NFкB, toll benzeri reseptörler ve bradikinin inhibisyonuyla COVID-19 tedavisinde, özellikle ARDS hastalarında önemli bir alternatif olabileceği görülmüsstür ${ }^{[67]}$. İran'daki randomize kontrollü bir calıșmada tedavisine nano-kurkumin eklenen COVID-19 hastalarında interlökin-1 $\beta$, IL-6 gibi inflamatuvar sitokinlerde belirgin azalma olurken TNF- $\alpha$ ve interlökin-18 düzeyinlerinde anlamlı değișiklik saptanmamıștır[68]. Henüz literatürde yeterli calıșma olmasa da ARDS gelisen veya inflamasyonun fazla olduğu COVID-19 hastalarında tedavide göz önünde bulundurulabilir.

12. Probiyotikler: İmmün sistem de dahil olmak üzere neredeyse tüm sistemleri etkilemekte olan probiyotikler; antimikrobiyal peptit üretimini, antikor ve sitokin oluşumunu, T hücre farkllașmasını arttırarak immün sistem üzerinde olumlu etkide bulunmaktadırlar. Akciğerde immünomodülasyon, antiviral aktivitede artıș ile respiratuvar virüslere karșı koruma sağlamaktadırlar ${ }^{[69]}$. Probiyotik desteğinin üst solunum yolu infeksiyonlarına etkisini inceleyen derleme bir çalsșmada probiyotik alanlarda üst solunum yolu infeksiyonunun, antibiyotik kullanımının ve hastalık nedenli is gücü kaybının daha az olduğu görülmüștür ${ }^{[70]}$. COVID-19 gastrointestinal sistem-akciğer yolağında değișikliklerle disbiozise neden olabilmektedir. Bunun sonucunda bakteriyel translokasyona bağlı sekonder infeksiyonlar ve hiperinflamasyon ortaya cıkmaktadır. Bu nedenle COVID-19 tedavisinde probiyotiklerin rol oynayabileceği düsünülmektedir ${ }^{[71]}$. Bu rolü ACE2 
inhibisyonu, immün sistemin güclenmesi, intestinal floranin tekrar normalizasyonu, viral infeksiyonlara karșı koruma ve komorbiditelere karșı yarar göstererek oynamaktadır ${ }^{[72]}$. Ayrıca probiyotiklerin immün sistemi kuvvetlendirici etkileri göz önünde bulundurularak COVID-19 tedavisinde kullanılabileceğini ileri süren birçok yayın bulunmaktadır ${ }^{[73,74]}$.

\section{SONUCุ}

Ele aldığımız 12 adet destek ürünün gerek in-vitro ve hayvan deneyleri, gerekse insan çlıșmalarında immüniteyi desteklediği gösterilmiștir. COVID-19'un önlenmesi ve tedavisi için destek ürünlerle ilgili randomize kontrollü calıșmalar devam etmekle birlikte $\mathrm{D}$ vitamini, $\mathrm{C}$ vitamini ve çinko ile ilgili çalısmalar öne çımaktadır. Riskli hasta gruplarında kullanımları tavsiye niteliğindedir, toksisite riski açısından özellikle D vitamini ve cinko güvenli aralıkta olmalıdır. Efor kısıtlılığ1, kardiyovasküler tutulum, olfaktör sinir benzeri nöronal tutulum, gastrointestinal tutulum, öksürük gibi pek cok durumda her bir destek tedavinin monoterapi ya da kombine tedavi olarak semptomatik olumlu etkisi öne sürülse de yeterli bilimsel kanıt bulunmamaktadır. Özellikle, omega-3 gibi antiinflamatuvar etkiye sahip, ayrıca yan etki açsindan daha masum olan immünomodulatör etkili destek ürünlerin kritik hastalarda abartılı bağıșıklık yanıtı baskıladığı öne sürülmektedir; sitokin fırtınası, ARDS ve mortalite üzerine etkilerinin randomize kontrollü çalıșmalarla desteklenmesi gerekmektedir. Epigenetik farklılıkları da kapsayacak sekilde daha geniș ve ceșitli etnik gruplarda daha fazla randomize kontrollü çalıșmaya ihtiyaç vardır.

\section{ÇIKAR ÇATIŞMASI}

Yazarlar bu makale ile ilgili herhangi bir c1kar çatıșması bildirmemișlerdir.

\section{KAYNAKLAR}

1. World Health Organization (WHO). Coronavirus Disease (COVID-19) Dashboard. Available from: https://covid19. who.int/ (Accessed date: 12/04/2021).

2. Pan $H$, Peto R, Henao-Restrepo AM, Preziosi MP, Sathiyamoorthy V, Abdool Karim Q, et al. Repurposed antiviral drugs for Covid-19 - Interim WHO Solidarity trial results. N Engl I Med 2020;384:497-511.

3. Sterne JAC, Murthy S, Diaz JV, Slutsky AS, Villar J, Angus DC, et al. Association between administration of systemic corticosteroids and mortality among critically ill patients with COVID-19: A meta-analysis. JAMA 2020;324(13):1330-41.
4. Galmés S, Serra F, Palou A. Current state of evidence: influence of nutritional and nutrigenetic factors on immunity in the COVID-19 pandemic framework. Nutrients 2020;12(9):2738.

5. Greiller CL, Martineau AR. Modulation of the immune response to respiratory viruses by vitamin $D$. Nutrients 2015;7(6):4240-70.

6. Jolliffe DA, Camargo CA Jr., Sluyter JD, Aglipay M, Aloia JF, Ganmaa $D$, et al. Vitamin $D$ supplementation to prevent acute respiratory infections: a systematic review and meta-analysis of aggregate data from randomised controlled trials. Lancet Diabetes Endocrinol 2021;9(5):276-92.

7. Grant WB, Lahore $H, M c D o n n e l l ~ S L$, Baggerly CA, French $C B$, Aliano JL, et al. Evidence that Vitamin D supplementation could reduce risk of influenza and COVID-19 infections and deaths. Nutrients 2020;12(4):988.

8. Hastie CE, Pell JP, Sattar N. Vitamin D and COVID-19 infection and mortality in UK Biobank. Eur I Nutr 2021; 60(1):545-8.

9. Liu N, Sun J, Wang X, Zhang T, Zhao M, Li H. Low vitamin $D$ status is associated with coronavirus disease 2019 outcomes: a systematic review and meta-analysis. Int J Infect Dis 2021;104:58-64.

10. Teshome A, Adane A, Girma B, Mekonnen ZA. The Impact of Vitamin D Level on COVID-19 Infection: Systematic Review and Meta-Analysis. Front Public Health 2021;9:624559.

11. Radujkovic A, Hippchen T, Tiwari-Heckler S, Dreher S, Boxberger $M$, Merle U. Vitamin D deficiency and outcome of COVID-19 patients. Nutrient 2020;12(9).

12. Murai IH, Fernandes $A L$, Sales $L P$, Pinto AJ, Goessler $K F$, Duran CSC, et al. Effect of a single high dose of vitamin $D 3$ on hospital length of stay in patients with moderate to severe COVID-19: A Randomized Clinical Trial. JAMA 2021;325(11):1053-60.

13. Wang R, DeGruttola V, Lei Q, Mayer KH, Redline S, Hazra $A$, et al. The vitamin D for COVID-19 (VIVID) trial: $A$ pragmatic cluster-randomized design. Contemp Clin Trials 2021;100:106176.

14. Boulkrane MS, Ilina V, Melchakov R, Fedotova J, Drago F, Gozzo L, et al. COVID-19 disease and vitamin D: A mini-review. Front Pharmacol 2020;11:604579.

15. Carr AC, Maggini S. Vitamin C and Immune Function. Nutrients 2017;9(11):1211.

16. Gorton $H C$, Jarvis $K$. The effectiveness of vitamin $C$ in preventing and relieving the symptoms of virus-induced respiratory infections. J Manipulative Physiol Ther 1999;22(8):530-3.

17. Douglas RM, Chalker EB, Treacy B. Vitamin C for preventing and treating the common cold. Cochrane Database Syst Rev 2000(2):Cd000980.

18. Abobaker A, Alzwi A, Alraied AHA. Overview of the possible role of vitamin $C$ in management of COVID-19. Pharmaco$\log \operatorname{Rep~2020;72(6):1517-28.~}$

19. Hiedra R, Lo KB, Elbashabsheh M, Gul F, Wright RM, Albano J, et al. The use of IV vitamin C for patients with COVID-19: a case series. Expert Rev Anti Infect Ther 2020;18(12):1259-61. 
20. Thomas S, Patel D, Bittel B, Wolski K, Wang Q, Kumar A, et al. Effect of high-dose zinc and ascorbic acid supplementation vs usual care on symptom length and reduction among ambulatory patients with SARS-CoV-2 infection: The COVID A to Z randomized clinical trial. JAMA Netw Open 2021;4(2):e210369.

21. Milani GP, Macchi M, Guz-Mark A. Vitamin C in the Treatment of COVID-19. Nutrients 2021;13(4):1172.

22. Singh R, Shaik L, Mehra I, Kashyap R, Surani S. Novel and controversial therapies in COVID-19. Open Respir Med J 2020;14:79-86.

23. Carr $A C$, Rowe $S$. The emerging role of vitamin $C$ in the prevention and treatment of COVID-19. Nutrients 2020;12(11):3286.

24. Olechnowicz J, Tinkov A, Skalny A, Suliburska J. Zinc status is associated with inflammation, oxidative stress, lipid, and glucose metabolism. J Physiol Sci 2018;68(1):19-31.

25. Skalny $A V$, Rink L, Ajsuvakova $O P$, Aschner $M$, Gritsenko $V A$, Alekseenko SI, et al. Zinc and respiratory tract infections: Perspectives for COVID-19 (Review). Int J Mol Med 2020;46(1):17-26.

26. Wessels I, Rolles B, Slusarenko AJ, Rink L. Zinc deficiency as a possible risk factor for increased susceptibility and severe progression of Corona Virus Disease 19. Br J Nutr 2021:119.

27. Meydani SN, Barnett JB, Dallal GE, Fine BC, Jacques PF, Leka $L S$, et al. Serum zinc and pneumonia in nursing home elderly. Am J Clin Nutr 2007;86(4):1167-73.

28. Barnett JB, Dao MC, Hamer DH, Kandel R, Brandeis G, Wu $D$, et al. Effect of zinc supplementation on serum zinc concentration and $T$ cell proliferation in nursing home elderly: a randomized, double-blind, placebo-controlled trial. Am I Clin Nutr 2016;103(3):942-51.

29. de Almeida Brasiel PG. The key role of zinc in elderly immunity: A possible approach in the COVID-19 crisis. Clin Nutr ESPEN 2020;38:65-6.

30. Jothimani $D$, Kailasam E, Danielraj S, Nallathambi $B, R a$ machandran $H$, Sekar P, et al. COVID-19: Poor outcomes in patients with zinc deficiency. Int J Infect Dis 2020;100:3439.

31. Perera M, El Khoury J, Chinni V, Bolton D, Qu L, Johnson $P$, et al. Randomised controlled trial for high-dose intravenous zinc as adjunctive therapy in SARS-CoV-2 (COVID-19) positive critically ill patients: trial protocol. BMJ Open 2020;10(12):e040580.

32. Domingo JL, Marquès $M$. The effects of some essential and toxic metals/metalloids in COVID-19: A review. Food Chem Toxicol 2021;152:112161.

33. Joachimiak MP. Zinc against COVID-19? Symptom surveillance and deficiency risk groups. PLoS Negl Trop Dis 2021;15(1):e0008895.

34. Tam M, Gómez S, González-Gross M, Marcos A. Possible roles of magnesium on the immune system. Eur J Clin Nutr 2003;57(10):1193-7.
35. Calder PC, Carr AC, Gombart AF, Eggersdorfer M. Optimal nutritional status for a well-functioning immune system is an important factor to protect against viral infections. Nutrients 2020;12(4):2696.

36. Alamdari NM, Afaghi S, Rahimi FS, Tarki FE, Tavana S, Zali A, et al. Mortality risk factors among hospitalized COVID-19 patients in a major referral center in Iran. Tohoku J Exp Med 2020;252(1):73-84.

37. Tang $C F$, Ding $H$, Jiao $R Q$, Wu $X X$, Kong $L D$. Possibility of magnesium supplementation for supportive treatment in $p a$ tients with COVID-19. Eur J Pharmacol 2020;886:173546.

38. Wallace TC. Combating COVID-19 and building immune resilience: a potential role for magnesium nutrition? I Am Col Nutr 2020;39(8):685-93.

39. Guillin OM, Vindry C, Ohlmann T, Chavatte L. Selenium, selenoproteins and viral infection. Nutrients 2019;11(9):2101.

40. Harthill M. Review: micronutrient selenium deficiency influences evolution of some viral infectious diseases. Biol Trace Elem Res 2011;143(3):1325-36.

41. Steinbrenner H, Al-Quraishy S, Dkhil MA, Wunderlich F, Sies $H$. Dietary selenium in adjuvant therapy of viral and bacterial infections. Adv Nutr 2015;6(1):73-82.

42. Im JH, Je YS, Baek J, Chung MH, Kwon HY, Lee JS. Nutritional status of patients with COVID-19. Int J Infect Dis 2020;100:390-3.

43. Heller RA, Sun Q, Hackler J, Seelig J, Seibert L, Cherkezov $A$, et al. Prediction of survival odds in COVID-19 by zinc, age and selenoprotein $P$ as composite biomarker. Redox Biol 2021;38:101764.

44. Kohn A, Gitelman J, Inbar M. Unsaturated free fatty acids inactivate animal enveloped viruses. Arch Virol 1980;66(4):301-7.

45. Kristine Koekkoek W, Panteleon V, van Zanten AR. Current evidence on $\omega-3$ fatty acids in enteral nutrition in the critically ill: $A$ systematic review and meta-analysis. Nutrition 2019;59:56-68.

46. Rogero $M M$, Leão $M C$, Santana TM, Pimentel $M$, Carlini GCG, da Silveira TFF, et al. Potential benefits and risks of omega-3 fatty acids supplementation to patients with $\mathrm{CO}$ VID-19. Free Radic Biol Med 2020;156:190-9.

47. Farough S, Karaa A, Walker MA, Slate N, Dasu T, Verbsky J, et al. Coenzyme Q10 and immunity: A case report and new implications for treatment of recurrent infections in metabolic diseases. Clin Immunol 2014;155(2):209-12.

48. Fan L, Feng Y, Chen GC, Qin LQ, Fu CL, Chen LH. Effects of coenzyme $\mathrm{Q} 10$ supplementation on inflammatory markers: A systematic review and meta-analysis of randomized controlled trials. Pharmacol Res 2017;119:128-36.

49. Chase M, Cocchi MN, Liu X, Andersen LW, Holmberg MJ, Donnino MW. Coenzyme Q10 in acute influenza. Influenza Other Respir Viruses 2019;13(1):64-70. 
50. Vassiliou AG, Mastora Z, Jahaj E, Keskinidou C, Pratikaki $M E$, Kampisiouli E, et al. Serum Coenzyme Q10 Levels are Decreased in Critically-III Septic Patients: Results From a Preliminary Study. Biol Res Nurs 2020;23(2):198-207.

51. Shenoy S. Coronavirus (Covid-19) sepsis: revisiting mitochondrial dysfunction in pathogenesis, aging, inflammation, and mortality. Inflamm Res 2020;69(11):1077-85.

52. Ouyang L, Gong J. Mitochondrial-targeted ubiquinone: A potential treatment for COVID-19. Med Hypothese 2020;144:110161.

53. Caruso F, Rossi M, Pedersen JZ, Incerpi S. Computational studies reveal mechanism by which quinone derivatives can inhibit SARS-CoV-2. Study of embelin and two therapeutic compounds of interest, methyl prednisolone and dexamethasone. J Infect Public Health 2020;13(12):1868-77.

54. Forman HJ, Zhang H, Rinna A. Glutathione: overview of its protective roles, measurement, and biosynthesis. Mol Aspects Med 2009;30(1-2):1-12.

55. Silvagno F, Vernone A, Pescarmona GP. The Role of Glutathione in Protecting against the Severe Inflammatory Response Triggered by COVID-19. Antioxidants (Basel) 2020;9(7):624.

56. Guloyan V, Oganesian B, Baghdasaryan N, Yeh C, Singh $M$, Guilford $F$, et al. Glutathione Supplementation as an Adjunctive Therapy in COVID-19. Antioxidants (Basel) 2020;9(10):914.

57. Horowitz RI, Freeman PR, Bruzzese J. Efficacy of glutathione therapy in relieving dyspnea associated with $\mathrm{CO}$ VID-19 pneumonia: A report of 2 cases. Resp Med Case Rep 2020;30:101063.

58. Sandvik A, Wang YY, Morton HC, Aasen AO, Wang JE, Johansen FE. Oral and systemic administration of beta-glucan protects against lipopolysaccharide-induced shock and organ injury in rats. Clin Exp Immunol 2007;148(1):168-77.

59. Feldman S, Schwartz HI, Kalman DS, Mayers A, Kohrman $H M$, Clemens $R$, et al. Randomized phase II clinical trials of wellmune WGP $[R]$ for immune support during cold and flu season. J Appl Res 2009;9(1-2):30-43.

60. Murphy EJ, Masterson C, Rezoagli E, O'Toole D, Major I, Stack $G D$, et al. $\beta$-Glucan extracts from the same edible shiitake mushroom Lentinus edodes produce differential in-vitro immunomodulatory and pulmonary cytoprotective effects - Implications for coronavirus disease (COVID-19) immunotherapies. Sci Total Environ 2020;732:139330.

61. Jawhara S. How to boost the immune defence prior to respiratory virus infections with the special focus on coronavirus infections. Gut Pathog 2020;12:47.

62. Salehi B, Mishra AP, Nigam M, Sener B, Kilic M, Sharifi-Rad $M$, et al. Resveratrol: A Double-Edged Sword in Health Benefits. Biomedicines 2018;6(3).
63. Malaguarnera L. Influence of Resveratrol on the Immune Response. Nutrients 2019;11(5).

64. Filardo S, Di Pietro M, Mastromarino P, Sessa R. Therapeutic potential of resveratrol against emerging respiratory viral infections. Pharmacol Ther 2020;214:107613.

65. Ranjbar A, Jamshidi M, Torabi S. Molecular modelling of the antiviral action of Resveratrol derivatives against the activity of two novel SARS CoV-2 and 2019-nCoV receptors. Eur Rev Med Pharmacol Sci 2020;24(14):7834-44.

66. Moghadamtousi SZ, Kadir HA, Hassandarvish P, Tajik H, Abubakar S, Zandi K. A review on antibacterial, antiviral, and antifungal activity of curcumin. BioMed Res Int 2014;2014:186864.

67. Babaei F, Nassiri-Asl M, Hosseinzadeh H. Curcumin (a constituent of turmeric): New treatment option against COVID-19. Food Sci Nutr 2020;8(10):5215-27.

68. Valizadeh H, Abdolmohammadi-Vahid S, Danshina S, Ziya Gencer $M$, Ammari A, Sadeghi A, et al. Nano-curcumin therapy, a promising method in modulating inflammatory cytokines in COVID-19 patients. Int Immunopharmacol 2020;89(Pt B):107088.

69. Hill C, Guarner F, Reid G, Gibson GR, Merenstein DJ, Pot B, et al. Expert consensus document. The International Scientific Association for Probiotics and Prebiotics consensus statement on the scope and appropriate use of the term probiotic. Nature Rev Gastroenterol Hepatol 2014;11(8):506-14.

70. Hao Q, Dong BR, Wu T. Probiotics for preventing acute upper respiratory tract infections. Cochrane Database Syst Rev 2015(2):Cd006895.

71. Akour A. Probiotics and COVID-19: is there any link? Lett Appl Microbiol 2020;71(3):229-34.

72. Olaimat AN, Aolymat I, Al-Holy M, Ayyash M, Abu Ghoush $M$, Al-Nabulsi AA, et al. The potential application of probiotics and prebiotics for the prevention and treatment of COVID-19. NPJ Sci Food 2020;4:17.

73. Baud D, Dimopoulou Agri V, Gibson GR, Reid G, Giannoni E. Using probiotics to flatten the curve of coronavirus disease COVID-2019 Pandemic. Front Public Health 2020;8:186.

74. Tiwari SK, Dicks LMT, Popov IV, Karaseva A, Ermakov AM, Suvorov A, et al. Probiotics at War Against Viruses: What is Missing From the Picture? Front Microbiol 2020;11:1877.

\section{Yazıșma Adresi/Address for Correspondence}

\section{Dr. Serdar CEYLAN}

Hacettepe Üniversitesi Tip Fakültesi,

Geriatri Bilim Dall,

Ankara-Türkiye

E-posta: serdar.ceylan@hacettepe.edu.tr 